Gastroenterology. 2009 May ; 136(5): 1495-1498. doi:10.1053/j.gastro.2009.03.024.

\title{
HuR and TTP:
}

\section{Two RNA Binding Proteins That Deliver Message From the 3' End}

\author{
SHRIKANT ANANT and \\ Department of Medicine, Section of Digestive Diseases and Nutrition and Department of Cell \\ Biology andOU Cancer Institute, University of Oklahoma Health Sciences Center, Oklahoma City, \\ Oklahoma
}

\section{COURTNEY W. HOUCHEN}

Department of Medicine, Section of Digestive Diseases and Nutrition, andOU Cancer Institute, University of Oklahoma Health Sciences Center, and VA Medical Center, Oklahoma City, Oklahoma

Colorectal carcinoma (CRC) is a leading cause of cancer deaths worldwide, and identification of new therapeutic targets remains an important endeavor. ${ }^{1}$ In this regard, molecular analyses regulating tumorigenesis have identified three classes of molecules broadly classified as receptors and signal transduction molecules (eg, epidermal growth factor receptor, vascular endothelial growth factor receptor, Ras), 2,3 transcription factors (peroxisome proliferator activated receptor- $\gamma$, nuclear factor $[\mathrm{NF}]-\kappa \mathrm{B}$ ) $, 4,5$ and inflammatory mediators (interleukin [IL]-6, IL-8). A central player in all these activities is cyclooxygenase-2 (COX-2), which catalyzes the key step in the conversion of free arachidonic acid to prostaglandins. Many studies have demonstrated that unregulated COX-2 expression is a rate-limiting step that occurs early in carcinogenesis. However, many side effects (eg, gastrointestinal ulceration and bleeding, platelet dysfunctions) have been ascribed to the COX-2-specific inhibitors. Consequently, the notion that down-regulating COX-2 gene regulation will provide therapeutic effects similar to the inhibitors without causing the unwanted side effects is appealing and is likely to have important therapeutic implications.

Most of the studies on COX-2 expression have dealt with transcriptional regulation through elements in the COX-2 promoter (Figure). For example, the $\beta$-catenin/TCF complex in the presence of Wnt signaling induces COX-2 transcription. ${ }^{6,7}$ Similarly, hypoxia induces COX-2 through the activation of NF- $\kappa \mathrm{B} .{ }^{8,9}$ Other factors such as C-EBP have also been shown to regulate COX-2 gene transcription. ${ }^{10,11}$ However, the level of steady-state mRNA is governed by a balance between gene transcription and mRNA degradation. Posttranscriptional regulation at the level of mRNA decay and translation is often aberrant in cancer cells, and is a hallmark of COX-2 expression. ${ }^{12}$

\begin{abstract}
Many oncogenes, growth factor, cytokine, and cell-cycle genes are regulated at the posttranscriptional level. Immediately after transcription, the native mRNAs undergo splicing. In addition, they are modified to include a 7-methylguanosine cap structure at the $5^{\prime}$ end and a poly(A) tail at the $3^{\prime}$ end, both of which increase stability of the transcript. ${ }^{13}$ In addition, continuing translation enhances mRNA stability, whereas premature and aberrant translation results in termination or impaired translation initiation, which promotes mRNA degradation. The major mechanism is by controlling the rate of mRNA turnover for transcripts bearing
\end{abstract}

\footnotetext{
(C) 2009 by the AGA Institute

Reprint requests Address requests for reprints to: Shrikant Anant, MD •. e-mail: shrikant-anant@ouhsc.edu; fax: (xxx) xxx-xxxx.. See "The mRNA binding proteins HuR and Tristetraprolin regulate cyclooxygenase 2 expression during colon carcinogenesis." by Young LE, Sanduja S, Bemis-Standoli K, et al, on page $\cdots \bullet$.
} 
destabilizing cis-elements. One such element, present in COX-2 3' untranslated region (UTR) is called AU-rich element ARE, which consists of AUUUA repeats and is broadly conserved in the human and mouse COX-2 $3^{\prime} \mathrm{UTRs}$ (76\% identity over 116-nt). ${ }^{14}$

To date, only a handful of regulatory factors have been identified that seem to control a large pool of target mRNAs, suggesting that a slight perturbation in the control mechanism may generate wide-ranging effects that could contribute to the development of a complex disorder such as cancer. ARE binding proteins (ARE-BPs) bind the AU-rich or U-rich sequences in the $3^{\prime}$ UTR to regulate localization, translation and degradation of mR-NAs encoding critical growth-response genes, cytokines, and cell-cycle regulatory proteins. ${ }^{15}$ At least 5 ARE-BPs have been identified that bind to the COX-2 ARE and affect stability and translation of COX-2 mRNA, including HuR, TIA-1, CUGBP2, RBM3, and Tristetraprolin (TTP; Table). ${ }^{16-24} \mathrm{HuR}$, which was first identified as tumor antigens in lung carcinomas of individuals with paraneoplastic neurologic disorder, is ubiquitously expressed. ${ }^{25}$ Dixon et al ${ }^{26}$ have previously demonstrated that HuR overexpression increases the stability of COX-2, VEGF, and IL-8 mRNAs. ${ }^{26}$ Moreover, HuR overexpression in LoVo cells increased COX-2 protein and enhanced the expression of a reporter gene containing the COX-2 $3{ }^{\prime} \mathrm{UTR} .{ }^{26}$ Young et al ${ }^{27}$ have now cast light on the expression of HuR and TTP. The TTP protein has been shown to reduce granulocyte-macrophage colony-stimulating factor mRNA stability via deadenylation, and also binds the COX-2 3'UTR. ${ }^{28,29}$ Sawaoka et al ${ }^{29}$ identified 2 COX-2 mRNAs in HCA-7 human CRC cell line differing in the length of their 3'UTRs. The longer one binds TTP and is repressed more rapidly than the shorter one that does not bind TTP. Thus, the shorter COX2 mRNA sustains a stronger COX2 expression. ${ }^{29}$ Other RNA binding proteins have also been demonstrated to bind to COX-2 3'UTR, but the functional significance of the interactions is currently not known (Table 1).

In this issue of $\mathrm{G}_{\text {ASTROENTEROLOGY }}$, Young et $\mathrm{a}^{27}$ have determined the expression of HuR and TTP during colon carcinogenesis. ${ }^{27}$ They demonstrate that HuR levels were increased, whereas TTP levels were reduced as early as in adenomas, which correlated well with expression of COX-2. Furthermore, there was an increase in the cytoplasmic localization of HuR. These confirm previous studies demonstrating that cytoplasmic localization rather than a significant overall increase in HuR expression is important in increasing the translation of ARE-containing mRNAs. This is also reminiscent of our work demonstrating that demonstrated increased CUGBP2 expression and subsequent cytoplasm localization of the protein. ${ }^{30}$ However, although HuR increased COX-2 mRNA translation, CUGBP2 was demonstrated to reduce the translation of COX-2 mRNA.

Thus, direct evidence is provided for HuR- and TTP-mediated regulation of COX-2 in this manuscript. When HuR levels go up, TTP levels are reduced. TTP is the only protein currently known to reduce COX-2 mRNA stability, which could be the reason for the reduced mRNA translation. Katsanou et $\mathrm{al}^{31}$ have demonstrated that HuR does not alter levels of target cytokine mRNAs in the absence of the destabilizing functions of TTP but that synergizes with the translational silencer TIA-1 to reduce the translation of these mRNAs. ${ }^{31}$ Similarly, Sureban et $\mathrm{al}^{32}$ showed that HuR and CUGBP2 interact and bind to COX-2 mRNA with a 1:1 stoichiometry, and this leads to translation inhibition. Furthermore, HuR interactions with another RNA-binding protein RBM3 significantly enhanced the translation of COX-2 mRNA. Hence, it should be noted that the context of HuR bind-ing to the ARE sequences is essential for its translation function.

Demonstration of a reduction in TTP levels also emphasizes the need for more investigation of the role of the HuR, TTP and other RNA binding proteins in the field of gastrointestinal cancers. Clearly, COX-2 is a major factor in CRC. However, there are multiple transcripts that encode AREs in their $3^{\prime} \mathrm{UTR}$. A question that remains is whether these proteins function in a 
similar manner with other such transcripts. Although some evidence suggests that these proteins also regulate inflammatory factors, it is sparse and further studies are warranted, especially in inflammation-mediated tumorigenesis. Also, the current study did not provide any evidence of mechanisms by which expression of HuR and TTP are regulated. The authors have alluded to promoter regions in the genes that encode these 2 proteins. An interesting observation is that the promoter for TTP consists of $\mathrm{CpG}$ islands, something we have observed in one of the promoters that encode CUGBP2 (Ramalingam S, Anant S, unpublished observations). Although the significance of this is currently unknown, it begs the question of whether factors that negatively affect COX-2 expression have similar regulatory mechanisms to silence their expression. Addressing this issue requires additional experiments and have potentially far-reaching implications at the basic science level, in addition to COX-2 in colon cancer.

\section{References}

1. Samoha S, Arber N. Cyclooxygenase-2 inhibition prevents colorectal cancer: from the bench to the bed side. Oncology 2005;69(suppl 1):33-37. [PubMed: 16210875]

2. Le Tourneau C, Vidal L, Siu LL. Progress and challenges in the identification of biomarkers for EGFR and VEGFR targeting anti-cancer agents. Drug Resist Updat 2008;11:99-109. [PubMed: 18515176]

3. Erman M. Molecular mechanisms of signal transduction: epidermal growth factor receptor family, vascular endothelial growth factor family, Kit, platelet-derived growth factor receptor, Ras. J Buon 2007;129(suppl 1):S83-94. [PubMed: 17935283]

4. Bren-Mattison Y, Meyer AM, Van Putten V, et al. Antitumorigenic effects of peroxisome proliferatoractivated receptor-gamma in non-small-cell lung cancer cells are mediated by suppression of cyclooxygenase-2 via inhibition of nuclear factor-kappaB. Mol Pharmacol 2008;73:709-717. [PubMed: 18055759]

5. Konstantinopoulos PA, Vandoros GP, Sotiropoulou-Bonikou G, et al. NF-kappaB/PPAR gamma and/ or AP-1/PPAR gamma 'on/off' switches and induction of CBP in colon adenocarcinomas: correlation with COX-2 expression. Int J Colorectal Dis 2007;22:57-68. [PubMed: 16506021]

6. Araki Y, Okamura S, Hussain SP, et al. Regulation of cyclooxygenase-2 expression by the Wnt and ras pathways. Cancer Res 2003;63:728-734. [PubMed: 12566320]

7. Kawasaki T, Nosho K, Ohnishi M, et al. Correlation of beta-catenin localization with cyclooxygenase-2 expression and CpG island methylator phenotype (CIMP) in colorectal cancer. Neoplasia 2007;9:569_ 577. [PubMed: 17710160]

8. Schmedtje JF Jr, Ji YS, Liu WL, et al. Hypoxia induces cyclooxygenase-2 via the NF-kappaB p65 transcription factor in human vascular endothelial cells. J Biol Chem 1997;272:601-608. [PubMed: 8995303]

9. Xu Q, Ji YS, Schmedtje JF Jr. Sp1 increases expression of cyclooxygenase-2 in hypoxic vascular endothelium. Implications for the mechanisms of aortic aneurysm and heart failure. J Biol Chem 2000;275:24583-24859. [PubMed: 10825178]

10. Khare S, Mustafi R, Cerda S, et al. Ursodeoxycholic acid suppresses Cox-2 expression in colon cancer: roles of Ras, p38, and CCAAT/enhancer-binding protein. Nutr Cancer 2008;60:389-400. [PubMed: 18444174]

11. Liu Q, Inoue H, Mahendran R. Transcriptional regulation of the COX-2 expression by nitric oxide in colon cancer cell lines. Oncol Rep 2008;19:269-274. [PubMed: 18097606]

12. Harper KA, Tyson-Capper AJ. Complexity of COX-2 gene regulation. Biochem Soc Trans 2008;36:543-545. [PubMed: 18482003]

13. Moore MJ, Proudfoot NJ. Pre-mRNA processing reaches back to transcription and ahead to translation. Cell 2009;136:688-700. [PubMed: 19239889]

14. Dixon DA. Dysregulated post-transcriptional control of COX-2 gene expression in cancer. Curr Pharm Des 2004;10:635-646. [PubMed: 14965326]

15. Barreau C, Paillard L, Osborne HB. AU-rich elements and associated factors: are there unifying principles? Nucleic Acids Res 2005;33:7138-7150. [PubMed: 16391004] 
16. Aguilera O, Munoz A, Esteller M, et al. Epigenetic alterations of the Wnt/beta-catenin pathway in human disease. Endocr Metab Immune Disord Drug Targets 2007;7:13-21. [PubMed: 17346200]

17. Cok SJ, Acton SJ, Morrison AR. The proximal region of the $3^{\prime}$-untranslated region of cyclooxygenase- 2 is recognized by a multimeric protein complex containing HuR, TIA-1, TIAR, and the heterogeneous nuclear ribonucleoprotein U. J Biol Chem 2003;278:36157-36162. [PubMed: 12855701]

18. Cok SJ, Acton SJ, Sexton AE, et al. Identification of RNA-binding proteins in RAW 264.7 cells that recognize a lipopolysaccharide-responsive element in the 3-untranslated region of the murine cyclooxygenase-2 mRNA. J Biol Chem 2004;279:8196-8205. [PubMed: 14662769]

19. Dixon DA, Balch GC, Kedersha N, et al. Regulation of cyclooxygenase-2 expression by the translational silencer TIA-1. J Exp Med 2003;198:475-481. [PubMed: 12885872]

20. Herranz M, Esteller M. DNA methylation and histone modifications in patients with cancer: potential prognostic and therapeutic targets. Meth Mol Biol 2007;361:25-62.

21. Lin NY, Lin CT, Chang CJ. Modulation of immediate early gene expression by tristetraprolin in the differentiation of 3T3-L1 cells. Biochem Biophys Res Commun 2008;365:69-74. [PubMed: 17971298]

22. Lopez de Silanes I, Galban S, Martindale JL, et al. Identification and functional outcome of mRNAs associated with RNA-binding protein TIA-1. Mol Cell Biol 2005;25:9520-9531. [PubMed: 16227602]

23. Lopez de Silanes I, Quesada MP, Esteller M. Aberrant regulation of messenger RNA 3'-untranslated region in human cancer. Cell Oncol 2007;29:1-17. [PubMed: 17429137]

24. Sureban SM, Ramalingam S, Natarajan G, et al. Translation regulatory factor RBM3 is a protooncogene that prevents mitotic catastrophe. Oncogene 2008;27:4544-4556. [PubMed: 18427544]

25. Nabors LB, Furneaux HM, King PH. HuR, a novel target of anti-Hu antibodies, is expressed in nonneural tissues. J Neuroimmunol 1998;92:152-159. [PubMed: 9916890]

26. Dixon DA, Tolley ND, King PH, et al. Altered expression of the mRNA stability factor HuR promotes cyclooxygenase-2 expression in colon cancer cells. J Clin Invest 2001;108:1657-1665. [PubMed: 11733561]

27. Young LE, Sanduja S, Bemis-Standoli K, et al. The mRNA Binding Proteins HuR and Tristetraprolin regulate cyclooxygenase 2 expression during colon carcinogenesis. Gastroenterology. 2009 000:000-000.

28. Carballo E, Lai WS, Blackshear PJ. Evidence that tristetraprolin is a physiological regulator of granulocyte-macrophage colony-stimulating factor messenger RNA deadenylation and stability. Blood 2000;95:1891-1899. [PubMed: 10706852]

29. Sawaoka H, Dixon DA, Oates JA, et al. Tristetraprolin binds to the $3^{\prime}$-untranslated region of cyclooxygenase-2 mRNA. A polyadenylation variant in a cancer cell line lacks the binding site. $\mathrm{J}$ Biol Chem 2003;278:13928-13935. [PubMed: 12578839]

30. Mukhopadhyay D, Houchen CW, Kennedy S, et al. Coupled mRNA stabilization and translational silencing of cyclooxygenase- 2 by a novel RNA binding protein, CUGBP2. Mol Cell 2003;11:113126. [PubMed: 12535526]

31. Katsanou V, Papadaki O, Milatos S, et al. HuR as a negative posttranscriptional modulator in inflammation. Mol Cell 2005;19:777-789. [PubMed: 16168373]

32. Sureban SM, Murmu N, Rodriguez P, et al. Functional antagonism between RNA binding proteins HuR and CUGBP2 determines the fate of COX-2 mRNA translation. Gastroenterology 2007;132:1055-1065. [PubMed: 17383427] 


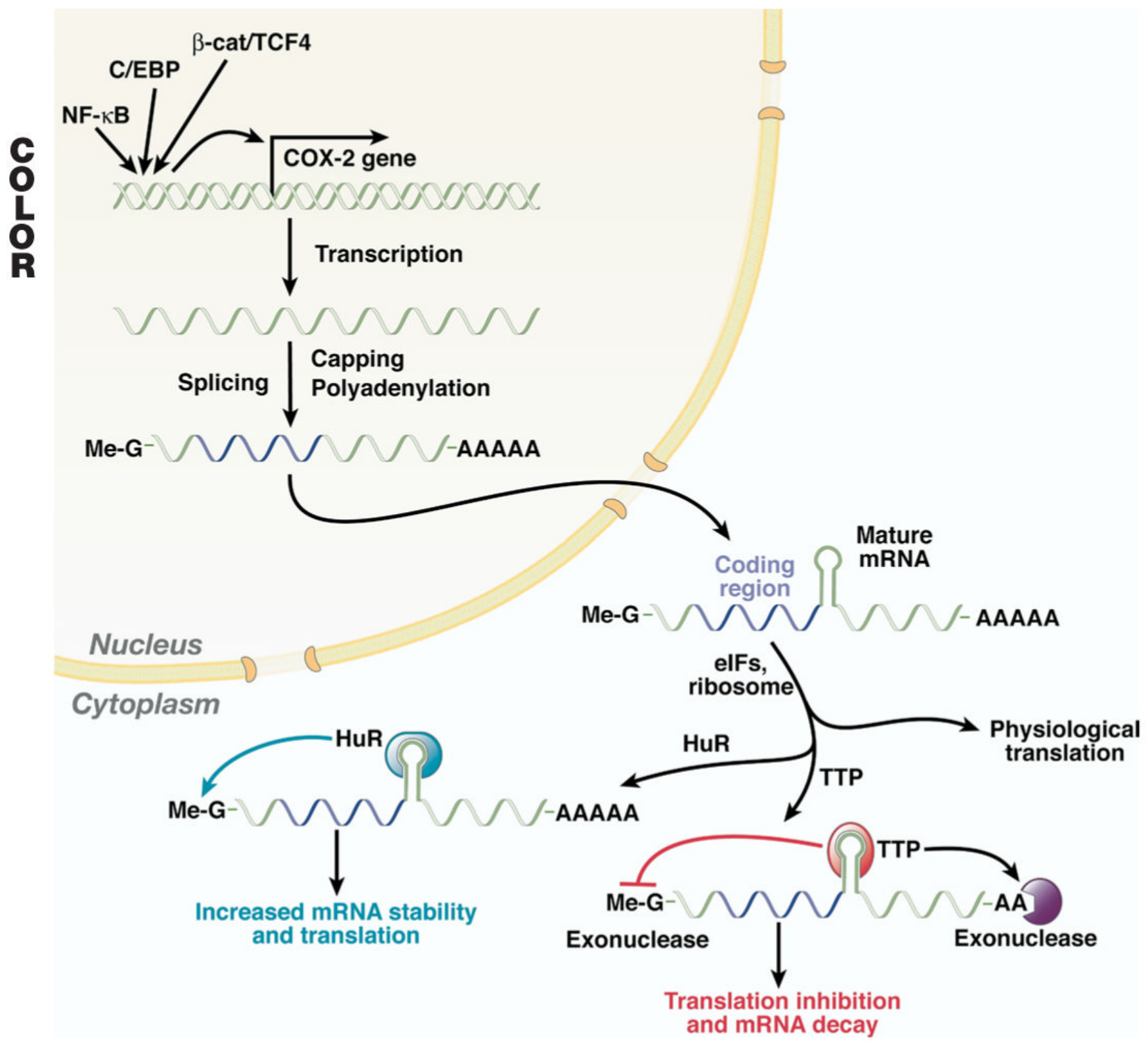

Figure.

Differential modulation of COX-2 mRNA translation by HuR and TTP. After transcription of the COX-2 gene, which can be induced by the actions of transcription factors $N F-\kappa \mathrm{B}, \mathrm{C} / \mathrm{EBP}$ and $\beta$-catenin/TCF-4, the transcript undergoes capping, splicing and polyadenylation, after which it is transported to the cytoplasm presumably by proteins involved in trafficking. Once in the cytoplasm, the transcript undergoes normal translation and subsequent degradation. ARE sequences in the 3' UTR assume a stem loop structure and interact with ARE-BPs to modulate the stability and translation. In this issue, Young et al demonstrate that in colon cancers HuR levels is increased resulting in increased HuR binding to COX-2 mRNA and consequent increase in stability and translation of COX-2 mRNA. In contrast, expression of TTP reduces in colon cancers, TTP binding would increase mRNA decay, which has been previously shown to occur through exonuclease-mediated deadenylation. 


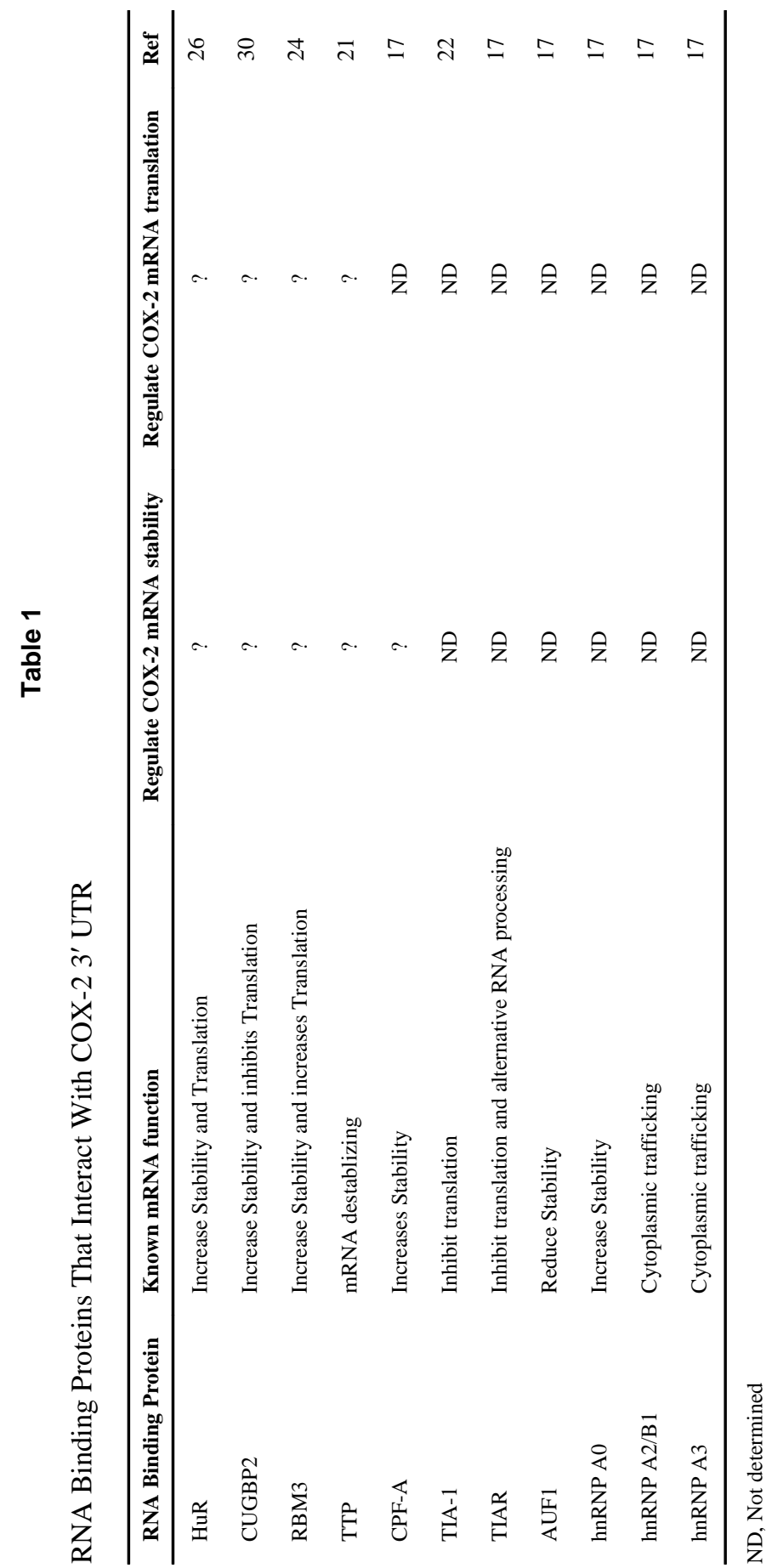

Gastroenterology. Author manuscript; available in PMC 2010 May 1. 